\title{
'No longer exiled, but protagonists'. The FILEF (Italian Federation of Migrant Workers and Families) and European human rights discourse in the 1970s
}

\author{
Francesco Vizzarri* \\ Department of History and Cultural Studies, Justus Liebig University of Gießen, Germany
}

(Received 25 June 2020; final version accepted 7 March 2021)

\begin{abstract}
This article examines the contribution of the FILEF (Federazione Italiana Lavoratori Migranti e Famiglie) to the European debate on the human, social and civil rights of migrant workers during the 1970s. Through the project of an 'International Statute of Migrant Workers' Rights', presented to the European Parliament in 1971, FILEF submitted a proposal for the reform of the 1968 Community Regulation on the Free Movement of Migrant Workers in Europe in order to extend to workers from non-European countries the same rights and protections accorded to those from the EEC area. The analysis is focused on the discussion around the proposal in the committees of the European Parliament as well as on the debate that developed within the transnational network of the FILEF during the international conferences organised by the Federation from the mid-1970s until the early 1980s.
\end{abstract}

Keywords: FILEF; Italian emigration after 1945; Italian associations abroad; human rights; European Parliament; transnationalism.

\section{Introduction}

The associations of Italian migrant workers represent a central aspect of the history of Italian emigration after the Second World War. In the past 20 years historiographic investigations have focused mainly on the analysis of the cultural and socio-political aspects of the associative networks, on the one hand by analysing the role of cultural circles in the assistance and integration of Italian workers, and on the other hand by dwelling on the transnational lifestyle of Italian communities abroad (Colucci 2001 and 2008; Palidda 2005; Ricciardi 2013; Caruso 2019). Since the 1960s the associative networks of Italian migrants, already active since the 1950s in the European countries of immigration, experienced a process of progressive 'stabilisation' (Colucci 2001, 426) in conjunction with the consolidation of migration flows and the introduction of free movement in the European Economic Community (hereafter EEC). Alongside the traditional forms of mutualism and legal and economic assistance to Italian workers abroad - carried out mostly by the Catholic Missions, the Caritas and the trade unions, which were fundamental reference points for Italian communities - larger organisations based at national, regional or provincial level also spread from the end of the 1960s onwards (Colucci and Sanfilippo 2010, 27; Sanfilippo 2011,368). The birth of this new type of 'umbrella' organisation is also partly the result of a process of sensitisation of the Italian political class, in particular of the main political parties, Democrazia Cristiana (DC) and Partito Comunista Italiano (PCI). Both parties began to pay more

\footnotetext{
*Email: francesco.vizzarri@geschichte.uni-giessen.de
}

(C) The Author(s), 2021. Published by Cambridge University Press on behalf of the Association for the Study of Modern Italy. This is an Open Access article, distributed under the terms of the Creative Commons Attribution licence (http://creativecommons.org/licenses/by/4.0/), which permits unrestricted re-use, distribution, and reproduction in any medium, provided the original work is properly cited. 
attention to the migration phenomenon, not only because it was a fundamental aspect of economic and socio-political balance in Italy, but also because the increasing number of Italian communities abroad were a reservoir of votes and consensus (Battiston 2012, 21; Marin 2016, 72).

The establishing of the FILEF must necessarily be intended and understood as part of this process. During the 1970s, the Federation became the largest 'national' umbrella organisation of migrant workers related to the communist and socialist sphere (Battiston 2012, 22). Through a 'federal' structure, within which cultural circles and democratic associations could join the Federation without formally losing their autonomy, the FILEF spread mainly in the Benelux countries, the Federal Republic of Germany and Switzerland; outside Europe, especially in Australia (Marin 2016, 90; Battiston 2004 and 2012). Despite the fact that the FILEF was the largest organisation of migrants with a socialist or communist political background, there are still few monographic studies that deal with the reconstruction of its trans- and supranational activities. ${ }^{1}$ In this context, I intend, at least in part, to fill this gap. Through the investigation both of the setting up of the FILEF network in Italy and in the European immigration countries, and through the analysis of the principles and the policy objectives at the basis of the FILEF's action at an international level, this article aims to demonstrate the significant contribution the Federation made to the European political debate on human, social and civil rights for migrant workers.

I argue that the FILEF, through the proposal of an 'International Statute of Migrant Workers' Rights' (the so called 'White Paper'), acted as a 'mediator' between the associative network of Italian migrants abroad and the European institutions. In concrete terms, the FILEF started a discussion with the European Parliament and the European Commission, including a specific discourse on human rights and developing a project with the aim of strengthening the unity of the democratic working class and migrant workers. At the centre of this project was the idea of a European solidarity based on the overcoming of the nation-state as a point of reference for migration governance and integration policies. During the 1970s the Federation, therefore, played a central role in the processes of Europeanisation and transnationalisation of the democratic movement of migrant workers. In this sense, this essay is therefore intended to shed more light on the role that migrant associations, which are de facto nongovernmental organisations and an essential part of European civil society, played in the processes of European integration, an aspect which has recently become the focus of attention of a considerable number of historiographical investigations (Ireland 1991; Kocka 2000; Bade 2003; Kaiser 2005; Lucassen, Feldman and Oltmer 2010; Kaiser and Meyer 2010; Laschi, Deplano and Pes 2020).

Through a transnational methodological approach $^{2}$ and on the basis of analyses of unpublished archive sources, ${ }^{3}$ I proceed as follows: in the first part, which also serves an introductory function, I will trace the development of the FILEF network from its initial stages until the beginning of the 1970s. In the second part, I will examine in particular the proposal for an 'International Statute of Migrant Workers' Rights', which the FILEF presented to the European Parliament three times, in 1971, 1973 and 1979. At the centre of the analysis will be both the process, with its different stages of discussion around the proposal, and the discourses which Paolo Cinanni, co-founder of the FILEF, developed on this topic at international congresses and conferences. In the third, concluding part, besides drawing the necessary conclusions, I will also illustrate possible paths for further historiographical analysis both of the FILEF and, more in general, of the Italian migrant associations after the Second World War.

\section{The FILEF network in Europe from its foundation to the early 1970s}

The FILEF was founded in Rome in 1967 at the behest of Carlo Levi, Paolo Cinanni and other politicians - deputies, trade unionists and intellectuals with a socialist, communist and 
liberal-democratic background (Breitenbach 1982, 114; De Donato and D'Amaro 2005, 309; Prontera 2017, 159 and 2018, 38; Caruso 2019, 241-2; Battiston 2012, 22-3; Marin 2016, 72). The initiative was the result of a series of analyses and reflections on Italian emigration and its social, political and economic consequences, which both Levi and Cinanni had already formulated in the months preceding the foundation itself. ${ }^{4}$ Far from considering the flow of young Italian labourers to northern European countries as a rebalancing element or an effective resolution for Italy's economic growth after the Second World War, Levi and Cinanni defined emigration flows as a 'forced exodus'. This resulted, particularly in southern Italy, in impoverishment and a depletion of human resources in favour of a 'zero cost enrichment' of the countries of immigration (Ricci 2016; Spatolisano 2012). This rigorous Marxist interpretation of the national and international migration phenomenon therefore saw the flows of labour as a consubstantial part of the Western capitalist and 'imperialist' political and economic system, in which the 'strong' economies operated a process of colonisation and exploitation. In order to counter this process - this, in essence, is the basic and main idea - Italian workers who emigrated abroad, together with their families who remained in Italy, should show solidarity with the international democratic movement and form a real 'unity' of programmes and intentions. ${ }^{5}$

On this theoretical basis, the FILEF organised its first National Assembly, which was held on 21 December 1967 at the Teatro Centrale in Rome. ${ }^{6}$ In an inspiring opening speech, Levi recalled the motivations behind the birth of a new democratic organisation, which was intended not only to be of mere assistance 'for migrants', but had to be 'made of migrants'. In other words, it should become a new 'democratic organism', within which workers outside Italy and their families at home could participate directly in the decision-making processes, becoming - to all intents and purposes - the real 'protagonists' of the migratory processes and dynamics on national and international level. ${ }^{7}$ The constitutive assembly in Rome was attended by several delegations of migrant workers' associations, including the delegation of the FCLIS (Federation of the Free Italian Colonies) from Switzerland, the association 'Leonardo Da Vinci' of Seraing/Liege (Belgium), AFI (Amicale Franco-Italienne) and the Italian-Belgian Friendship of Limburg, together with representatives of the Italian-Belgian cultural and recreational associations of Borinage and Charleroi. In addition to these associations, as mentioned in an article in L'Unità of 29 December 1967, there were also numerous ordinary Italian workers (mainly workers from Belgian and German steel and metallurgical industries), representatives of the CGIL (Confederazione Generale Italiana del Lavoro), representatives of INCA (Istituto Nazionale Confederazione di Assistenza) and other democratic associations, including UDI (Union of Italian Women). ${ }^{8}$ The participation of these delegations demonstrates, on the one hand, the openness of the Federation - already at the very beginning of its existence - to the actors of civil society and of the labour movement. On the other hand, it is evidence of the existence of connections and networks of inter-personal relationships and contacts, which pre-existed at the very foundation of the FILEF and operated in a network connected with the PCI and, more generally, with the world of migrant associations, in particular in the Benelux countries, Switzerland and Germany. ${ }^{9}$

The publication of the official bulletin of the Federation, simply called Emigrazione, began in November $1968 .{ }^{10}$ The magazine, distributed on the basis of monthly subscription within the clubs and member associations, was intended to be a 'permanent instrument' that could give 'voice' to Italian emigrants and become a place of 'autonomous expression' of their problems and the injustices they were suffering at their workplace and in their social lives. ${ }^{11}$ Only two years later the FILEF was already organising its second national conference, held in Rome at the Teatro Capranica. ${ }^{12}$ Similarly to what had happened two years earlier, there was a large participation of diverse Italian migrants' associations, politicians and trade unionists. ${ }^{13}$ The main result of the 
second assembly was to define, in a more precise way, the programmatic objectives and the reforms to be realised both in Italy and abroad. Among the various and numerous points that can be deduced from analysis of the documents, there were above all the reform of the European social fund for professional qualification; the teaching of Italian language and culture to the entire community of emigrants in public schools; the reform of assistance and welfare and the respect of employment contracts; a social housing programme in favour of Italians returning after their period of work abroad; and the recognition of the autonomous representations of emigrants at embassies and consulates, as well as a greater propensity for the recognition of associations as instruments of socialisation, participation and protection of emigrant workers. ${ }^{14}$ These points essentially constituted the backbone of the political and congressional activity of the FILEF throughout the 1970s.

The definition of the action programmes mentioned above, the implementation of projects at local and national level, were the result both of the decisions taken in Rome by the FILEF presidency - which followed precise political action strategies - and of a coordination of ideas and know-how which took place within the FILEF network in Italy and abroad. This happened on the one hand through collaboration with the Italian regions, which, starting from 1970, obtained greater constitutional autonomy and competence in the field of emigration and immigration (Colucci and Sanfilippo 2010, 28; Tintori 2016, 115), on the other hand, through working groups, round tables and meetings with representatives of political parties (in particular the PCI), the welfare network (INCA/CGIL), the ACLI (Christian Associations of Italian Workers) and the (newly established) associations of migrant workers with a regional basis, such as the USEF (Sicilian Union of Emigrants and Families) and especially the ALEF (Association of Friulian Emigrant Workers). ${ }^{15}$ Outside Italy, from 1971-4, there were an increasing number of memberships of preexisting Italian local associations, cultural and recreational clubs, which gradually became part of the FILEF network. As far as Belgium is concerned, the FILEF activity was immediately linked to that of the important non-profit association 'Leonardo Da Vinci', active since the 1960s in the area of Seraing/Liège (Caruso 2019, 340; Carta 2011, 250; Canovi 2011, 12). In France the diffusion of the Italian regional associations took place in the Lorraine area, in the north of Pas-de-Calais, and in Paris and Lyon, and took shape in the so-called 'Amicale Franco-Italienne', which gradually joined the FILEF (Palidda 2005). In the Federal Republic of Germany, in the first half of the 1970s, the 'Circolo Rinascita' in Munich (Prontera 2017, 158; 2018, 34-41), the 'Circolo ARCES' in Stuttgart (Lotterer 2014), the "Circolo Di Vittorio" in Frankfurt am Main (Schöneberg 1993) joined the FILEF. In addition, following the first German FILEF congress held in Frankfurt in March 1970, the FILEF-Germany headquarters was established in Cologne. ${ }^{16}$ At the same time, the FILEF co-organised significant international conferences during the 1970s. The first one was held in Amsterdam from 22 to 26 August 1971 on the initiative of the Anne Frank Foundation as part of the initiatives promoted by the UN, which had proclaimed 1971 the International Year against Racial Discrimination. ${ }^{17}$ The second was held in Wageningen (22-24 November 1974) ${ }^{18}$ and the third in Turin from 28 to 29 May $1977 .{ }^{19}$

\section{The FILEF 'White Paper': the proposal for an 'International Statute on the Rights of Migrant Workers'}

The above-mentioned transnational network constituted the socio-political space in which the debate on the issue of the human rights of migrant workers developed during the 1970s. This topic was a fundamental part of the statutory and programmatic aims of the FILEF. ${ }^{20}$ From 1968 onwards, also as a consequence of the increasing diffusion of the official bulletin Emigrazione among Italian communities abroad, the social, political and civil rights of workers 
occupied an increasing space, especially in the meetings of local Italian migrants' associations. These associations began to send the first reports of abuse, injustice and discrimination against Italian workers to the FILEF presidency in Rome. In the majority of the cases, these were letters of complaint, petitions and reports from Italian workers, especially those employed in the large metallurgic, steel and automotive industries in the Federal Republic of Germany. The actual dossiers, which were then published in the bulletin, highlighted both the poor hygienic and sanitary conditions of the so-called 'Baracken' (the lodgings made available for the guest-workers by German companies) and the various forms of marginalisation, discrimination, ghettoisation and social confinement ('Unterschichtung'), including episodes of real racism against Italian workers (Kammerer 1991 and 2005; Richter and Richter 2012, 45-59; Zölls 2019, 101-04; Pugliese 2006). This issue immediately became the centre of the political initiatives of the FILEF presidency. Already in 1969, in fact, Carlo Levi had started a parliamentary question to the Senate of the Republic in Rome (Battiston 2012, 21). ${ }^{21}$ It was a proposal to launch a parliamentary inquiry with two main aims: to analyse more closely the serious problems mentioned above, and to intervene more decisively in the composition of the Committee of Italians Abroad, which the Italian Ministry of Foreign Affairs had formed in the preceding years in order to support the Italian communities abroad. ${ }^{22}$

At the same time, in 1970, the FILEF began to write a draft petition to be submitted to the European Parliament (hereafter EP) and the Commission of the European Economic Communities (hereafter Commission), to which a proposal for a 'Statute on the rights of migrant workers' was attached. ${ }^{23}$ The so-called 'White Paper' on the condition of migrant workers in the Community area was presented for the first time on 23 November 1970 at the EP in Luxembourg. The proposal was submitted in the form of a petition (n. 4/70) with the subject 'Improvement of the situation of Italian emigrants in the Community and adoption of a European statute for emigrant workers' and was signed by Gaetano Volpe and Paolo Cinanni, both members of the FILEF presidency. ${ }^{24}$ The 'White Paper' is divided into several parts. The first part summarises the general characteristics and problems of economic migration in Europe. The second part, more specifically, deals with the living and working conditions of migrant workers: the workplace, social life, vocational training, relations with the native society and the authorities. This part also lists many of the direct witness accounts of Italian workers abroad and some of the complaint files collected by the FILEF in the previous months. The third part sets out the measures to be taken to ensure broader equality of treatment and greater participation of Italian migrants in the societies of arrival, as well as proposals to end the so-called 'exodus of labour' from Italy. In a fourth and final part, several social security problems related to the migration phenomenon are listed. ${ }^{25}$

The fundamental part of the 'White Paper' was actually the analysis of Regulation (EEC) No. 1612/68 of the European Council of 15 October 1968 on the freedom of movement for workers within the Community area. ${ }^{26}$ The criticism that the FILEF levelled at the Regulation was not against its substance, since large parts of the Regulation formally guaranteed equal rights to work, wages and social security treatment for domestic and foreign workers in the EEC. For the FILEF the problem was that these principles were in reality not fully respected by the countries of immigration, since 'national or regional legislation' prevailed over them. ${ }^{27}$ In other words: while the Regulation guaranteed the principles of freedom of movement of labour in the EEC, it did not, however - according to the FILEF - provide the necessary legislative instruments that could remove the obstacles to the effective improvement of workers' conditions. For the FILEF, the free movement of labour was not to be understood only in the sense of offering workers new economic opportunities in the EEC area. It was also supposed to provide for new, efficient actions to equalise social and welfare treatment for immigrant workers, to facilitate finding 
accommodation and, above all, to guarantee the exercise of civil and political rights. These requests were summarised in six points: 1) the modification of the EEC's regulation on the free movement of workers; 2) the extension of the measures on schooling to all the children of emigrant workers; 3 ) the effective reform and adjustment of the European Social Fund; 4) the extension of the rights and structures of participation of emigrants; 5) the adoption of an Italian regulation and an international statute for the rights of migrant workers; 6) the unification and improvement of legislation on social security. ${ }^{28}$ In the view of the FILEF the realisation of these points could only be achieved through a full participation of migrant workers in the decision-making processes regarding migration. Such participation was to be considered not only in terms of voting rights, but also as a greater participation by migrant workers in municipal and regional forms of associations (e.g. through the opening of membership in cultural circles, trade unions and political parties). ${ }^{29}$

According to the FILEF, a substantial modification of the Community regulation was therefore necessary. It had to be realised through the separation of the European regulations regarding the modalities of recruitment of foreign labour in the EEC from the normative apparatuses that aimed to regulate and facilitate the life of migrant workers in the arrival societies. The FILEF proposed, in short, a European and international legislation that was meant to have 'power of law' in all EEC countries and be valid for 'all migrant workers' living in the European Community. The intention of the FILEF was to eliminate the differentiation between 'Community workers' and 'non-Community workers' in the 1968 Regulation:

The Regulation must lay down measures to prevent restructuring processes representing a disqualification for migrants, and therefore cannot provide the so-called priority for workers from Member States, which is not even respected. Equality must extend to all workers in a unitary process of common and continuous progress, without distinction of nationality. ${ }^{30}$

On the basis of the documents submitted, the reasons given and the urgency with which the petition was submitted, the EP began an initial internal discussion as early as 19 January 1971, instructing the Social and Health Committee to carry out further investigation and verification on the discriminatory and exploitative cases brought up in the FILEF's petitions and reports. Once a rapporteur had been appointed by the EP in the person of Alfred Califice, the Committee organised a meeting in Rome at the end of April 1971 with representatives of the FILEF and other national Italian workers' organisations, including ACLI, UNAIE (National Union of Immigrant and Emigrant Associations), the catholic UCEI (Central Office for Italian Emigration), as well as some observers and representatives of Italian trade unions (especially the CGIL, Italian General Confederation of Labour). ${ }^{31}$

At the meeting in Rome, which was attended by other members of the European Commission (including Albert Coppè), the secretary of the FILEF, Gaetano Volpe, summarised the main proposals of the 'Statute', insisting particularly on two points: the improvement of the EEC Regulation to ensure effective equality of treatment between EEC and non-EEC workers by unifying and improving social security legislation and by extending the participation possibilities for migrants, especially the right to vote and the right of association. ${ }^{32}$ Both these points were basically supported by the representatives of the European Commission present at the meeting. In fact, during the discussion they made explicit mention of an important document written by the Commission and entitled 'Preliminary guidelines for a Community social policy programme'. It had been developed at the beginning of the year and already submitted for validation by the EP. ${ }^{33}$ In this document, the Commission listed the measures needed to improve the European policy on migrant workers, which urgently needed to be adapted to cope with the changing patterns of European migration. At the beginning of the 1970s, in fact, the flows of EU workers within the EEC area 
were clearly decreasing, while the arrivals of migrant workers from so-called 'third countries' (i.e. European countries which were not part of the EEC and non-European countries such as Turkey or North African countries) were increasing. According to the Commission this evolution of the immigration dynamics in the EEC area entailed a series of 'new' problems for the EEC institutions and their migration governance. The arrival of labourers from non-EEC countries, whose habits, customs and traditions were very distant and different from those of Europe, could increase the difficulties of adaptation in the societies of arrival and, consequently, the risk of social conflicts with the local workers. ${ }^{34}$ The Commission declared itself ready to monitor the application of the rules with regard to the movement of workers (especially those from the 'third countries'). ${ }^{35}$

Paolo Cinanni also referred to this same document in an article in the FILEF bulletin Emigrazione published in June. While positively assessing the Commission's efforts, he nevertheless still saw in the document a 'dangerous discrimination' between EEC and non-EEC labourers:

... [I]n order to have a truly integrated labour market, all discrimination and differences in treatment must be eliminated. But the Commission document itself speaks instead of 'Community preference in the recruitment of workers', and proposes to 'extend in stages the benefits of Community workers to all immigrant labour forces in the Community, starting with workers from the associated countries'. Here is the labour market divided into local workers; Community and non-Community workers: Community and 'associated' workers; 'seasonal' and 'frontier workers', etc. Yet workers provide the same work: for it, everyone is entitled, in relation to the time of employment, to the same treatment. ${ }^{36}$

Behind this line of argumentation we recognise, in fact, not only a clear willingness to overcome the 1968 Regulation through the elimination of any legal and socio-economic differentiation between national and migrant manpower, but also the overcoming of the criterion of 'nationality' as a legislative, normative and governmental reference point to manage the circulation of labour within the EEC countries. The following passage helps us to better understand Cinanni's view:

But even for this, to be able to unite all working forces, of whatever nationality, for the achievement of these general aims, it is necessary to fight for the more immediate aims of the workers, on the basis of a platform of claims which embrace the aspirations of everyone to improve their own conditions of work and life. With the unification within the EEC - of the legislation of labour to secure for all workers the same rights .... With the adoption of a 'Statute of migrant workers' so that they will have legal rights in all the countries of the Community and guarantees to all without distinction of that most essential equality of treatment; with the full recognition of all the rights of a human being, who must be able to develop in all freedom according to his own abilities, taking into account the level reached by technical and scientific progress and the new relations between the social powers struggling in a united Europe. ${ }^{37}$

After the first months of public debate, the FILEF proposal was finally discussed by the EP at its sitting of 21 September 1971. The speeches of the Members of the EP (hereafter MEPs) show, on the one hand, almost unanimous support for an initiative which was indeed considered a step forward in the European and international debate on the living and working conditions for many migrants in Europe. ${ }^{38}$ On the other hand, however, the basic dilemma of the proposal became evident. This was connected to the jurisdictional form to be given to an international Statute, which - at least in its theoretical formulations - clashed with Community regulations. It was Alfred Coppè, the European Commissioner for Jobs and Social Rights, who had already attended the meetings in Rome, who underlined this difficulty. On the one side, he pointed out, the Commission was trying to find a solution in order to achieve 'equal treatment for all migrant workers, whether they belong to the Community or to third countries'. On the other side, he stressed that this would be done accordingly with the so-called 'Community preferential clause' foreseen in the 1968 Regulation, which already provided a series of protections concerning not only the modalities 
of recruiting, but also social protection and the defence of civil rights. ${ }^{39}$ Coppè firmly reiterates that this part of the Regulation would not be called into question. ${ }^{40}$ Taking into account this 'preferential clause', Coppè gave an assurance, however, that the Commission would proceed in two ways. First, it would commission empirical studies to shed light on the complaints brought forward by the FILEF, and second it would cooperate directly with migrants' associations, especially with the 'Italian migrant workers', to solve 'all the issues of concern to them'. On these conclusions and partial promises guaranteed by the Commission, the motion for a resolution was adopted by the $\mathrm{EP}^{41}$ In the following months the Commission asked a professor at the University of Louvain (Belgium) to draw up a socio-scientific study on the condition of migrant workers in the Community area. However, this study was not followed by other significant initiatives of the Commission and the issue was temporarily shelved. ${ }^{42}$

The matter would have to wait until May 1973 before it was taken up and brought to attention again. The FILEF - after a lively conference period both in Italy and in the West European countries of immigration ${ }^{43}$ - presented (for the second time) a petition for an international Statute of migrant workers' rights to the EP. Concurrently, one year later, the UNAIE also presented a petition to the EP which contained a very similar proposal for a 'European', not 'international', statute of rights for migrant workers. ${ }^{44}$

The petition was analysed in March 1974 by the European Committee on Social Affairs and Employment and a very detailed report was written by Egbert Wieldraaijer (European Socialist Group). ${ }^{45}$ In addition to stressing, in a very critical way, the delays of the Commission with regard to a topic considered of central importance for European politics, Wieldraaijer indicated the proposal for an 'international' statute by the FILEF as the resolution to be preferred over the UNAIE proposal. Even if the latter would have had fewer legal obstacles because of its similarity to the existing EEC Regulation, there was no doubt for him that a Charter of migrant workers' rights 'should be drawn up as soon as possible to protect all foreign workers, regardless of their nationality'. His arguments were basically fourfold. First of all, he recalled that the emigration of the labour force from EEC countries (such as Italy) was progressively decreasing, while the number of non-Community workers entering the EEC was growing. Secondly, Community emigrants were already protected, at least in part, by the 1968 Regulation, especially regarding social security and civil rights. Thirdly, the integration of Community migrant workers was 'relatively easier' than that of workers of Turkish or North African origin, who were facing often insurmountable barriers of language, customs and religion. Finally, according to Wildraaijer, it was 'unfair to create further discrimination between EEC workers and workers from third countries'. 46 The second motion for a resolution was therefore discussed and approved by the EP at its sitting on 12 June $1974 .^{47}$

In the following months, the FILEF intensified its efforts to take forward the Charter proposal. In particular, there was a unity of intent and a close collaboration between the three main Italian migrant organisations (FILEF, ACLI and UNAIE) and a series of meetings and appointments that sealed this alliance. The first important occasion to demonstrate this 'unity of intent' around the FILEF proposal was the European Congress of Italian Emigration, held in Brussels from 22 to 24 July $1974 .{ }^{48}$ The congress was attended by more than 27 representatives of Italian organisations, including mainly ACLI, UNAIE and ALEF, but also trade unions and various Italian political parties. The meeting was also attended by Luigi Girardin, member of the Committee on Social Affairs and Employment of the EP. In his speech, he emphasised the efforts of the European Commission, which was working on the definition of a 'Statute' for the rights of the emigrant 'following the presentation of proposals made by the two main organisations of emigrants in the European ambit, the FILEF and the UNAIE'. According to Girardin, the Committee on Social 
Affairs and Employment was already working on a Report regarding the Social Action Programme submitted by the Commission to the European Council (Doc. 216/73) in which a large part of the programme was dedicated to the measures to be taken for a real improvement of the working and living conditions for 'all migrant workers' and their families, combined with a community action programme and a coordination of the immigration policies of the member states with regard to third countries. ${ }^{49}$ Furthermore, Girardin recalled that, similarly to what had happened two years earlier (the first meeting in Rome), a further meeting between representatives of the European institutions and those from the Italian associations would be held in Rome as early as October 1974 in order to come to a unanimous decision regarding the juridical form to be given to the 'Statute'. In this sense he invited the organisations to clarify whether the Charter should be defined in an 'international' way or be valid only for EEC workers. ${ }^{50}$

The official response by the FILEF was not long in coming. In his speech at the second congress on international migration, held in Wageningen in 1974, Cinanni firmly reiterated the importance of an international Statute that would guarantee the rights 'to all workers' and could serve as an instrument of legal protection for migrant workers and as a basis for common international policies for trade unions and the working class in the defence of labour rights. Cinanni's argumentation followed the same lines that Wieldraaijer had pursued in his report in March 1974:

Even the European Committee on Social Affairs and Employment declares ... that preference should be given to a Charter applying to all foreign citizens residing in the Community, and not only to the citizens of member states of the EEC, exactly because the number of emigrants from other countries is by far greater, because the emigrants from EEC member states are already better protected and because it is unjust to create discrimination between workers from EEC member states and workers from other countries. ${ }^{51}$

The FILEF's position became more precise during the meeting between the EEC representatives, the Italian government and trade unions and migrants' organisations, already announced by Luigi Girardin in the July Assembly and held in Rome in October 1974 in the Chamber of Deputies. $^{52}$ In the discussion, the FILEF firmly returned to the issue of discrimination in European regulations and the differentiation between EEC and non-EEC labourers, stressing that the lack of satisfactory European migration policies was linked to 'structural deficiencies and legislative gaps' related to a European political system which considered only economic interests to be of primary importance, without looking at rights of migrant workers and the rights of the weakest:

The FILEF has never accepted the so-called 'Community clause', which would mean 'discrimination' for non-EEC workers and ultimately also for other workers. When workers are divided, however, they only serve the interests of the economically dominant classes. In general, Europe cannot be made by preserving what is there, but by working to unite the labour forces that want reforms and are capable of contributing to them, for a real civilisation and humanity, and to heal the crisis that comes out of the way Europe has been conceived so far. ... One thing is certain about the location of emigrants in Europe (EEC or non-EEC): a European construction that places emigrants at the lowest levels cannot be considered. The Community has found that, for example, in Germany only 2 per cent of emigrants have obtained a qualification, and only 3 per cent have specialised; that emigrants have cooperated to achieve high levels of economic expansion and have had few opportunities for progress; that non-EEC nationals are the main victims of existing discrimination; that emigrants are generally excluded from social benefits and from the management of public activities and services. ${ }^{53}$

As we can see, the FILEF strongly reaffirmed its preference for an 'international Statute' for migrant workers and called on the EC Commission to act accordingly. ${ }^{54}$ The intense season of debates, conventions, congresses and conferences, which - as we have seen - developed 
throughout the summer and autumn of 1974, did not take long to bear fruit. At the end of the year, in fact, the Commission confirmed its intention to implement action programmes in favour of migrant workers and their families. A Commission information memo (P-85/74) lists two major goals. First, to ensure equal treatment of Community and non-Community labourers (especially regarding the payment of family allowances for children who remained in the country of origin). Second, to assure a series of measures to be realised 'by 1980' which would improve the political rights at municipal level by the setting up of a system of consultative organisations which could ensure a voice for migrants' decisions taken at local level. In this sense, the Commission envisaged a very precise plan and several measures. They included, for Community nationals, the introduction of a uniform system for the payment of family benefits, which was to be gradually extended to third-country nationals. At the same time, the Commission also planned to introduce vocational training and language courses and implement social services for migrants through a housing financing scheme. ${ }^{55}$

After this - at least initial and partial - acknowledgement by the Commission to adopt appropriate measures to overcome the discrimination and injustice suffered by migrant workers at Community level, the FILEF began, in the following years, to strengthen the partnership formed with other organisations of Italian migrants abroad. This led to the First National Conference on Emigration, held in Rome in March 1975, ${ }^{56}$ and to the third international congress on migration, co-organised by the FILEF and held in Turin in $1977 .{ }^{57}$ The main result of the latter was the creation of an International Committee for Migration in Europe. One of the objectives of the Committee was to carry out a 'democratic action' involving not only ethnic organisations of immigrant workers and local trade unions, but also collaborating directly with the European institutions, taking part in the decision-making processes related to the EEC migration policy. This is how Paolo Cinanni, elected chairman of the Committee, expressed himself at the end of the congress proceedings:

In order to carry out this action of ours in a continuous and coordinated manner, the Promoter Committee puts forward the proposal that at the end of its work, this Third Congress of ours should appoint an International Committee for information and coordination of our common action in Europe, which, as its first commitment, will promote a number of meetings with the authorities of the EEC Commission, the EP ... in order to arrive - with their collaboration - at a conference on labour immigration in European countries, similar to the one held in Italy in 1975, which launched an interesting process of participation of the workers concerned, aiming at the self-management of the organisms of our emigration. ${ }^{58}$

The Committee, made up of representatives of large international 'umbrella' migrant organisations, met every six months at the EEC institutions in Brussels and Luxembourg and over the following two years from 1977 to 1979 developed a very concrete programme of action concerning the granting of 'European citizenship' rights also to EEC and non-EEC workers (who had been permanently resident in one of the EEC countries for at least two years). The Committee also worked on the project for the adoption of a European law for the right to vote for local authorities for all residents, including immigrant workers and their families. At the end of 1979 the activities of the European Committee on Emigration led, for the third (and last) time, to the submission of a proposal for a FILEF Statute to the EP. ${ }^{59}$ In November, Paolo Cinanni wrote directly to the President of the EP, Simone Veil. In his letter Cinanni called on the EP to take up the question of the international Statute and, at the same time, to include representatives of the European Emigration Committee in the social European institutions, to provide them with a seat in the secretariat and also with a 'financial contribution for the very functioning of the Committee'. Indeed, 
on 13 November, Veil agreed to meet the representatives of the Committee. Two days later, on 15 November, the motion for a resolution was submitted to the EP. ${ }^{60}$

Unlike the first two petitions, there was no discussion in the EP in this case, because in the same year two other petitions - on a very similar subject and presented by the two major parliamentary groups (Christian Democrats and Socialists) - were discussed and voted on. ${ }^{61}$ The greater interest of a growing number of MEPs in the matter regarding the rights of migrants, as well as the fact that this time it was not an external non-governmental organisation that tabled motions for resolutions, but MEPs themselves, led to a certain acceleration of the decision-making process in the European institutions in Luxemburg and Brussels. Two important documents are evidence of this trend, a consultation held in 1979 and a dossier of 1980. In both documents, the Commission was clearly required to ensure the free movement of Community migrant workers, to stimulate the coordination of national policies on migrants from third countries, to promote the abolition of discrimination in the workplace and to adopt specific social and educational measures for all migrant workers in the EEC area, regardless of their country of origin (Gilardoni, D'Odorico and Carrillo 2015, 29). Finally, in 1981 the Committee also accepted some of the proposals contained in the two petitions mentioned above, recognising the juridical and legal practicability of overcoming excessive distinctions and differentiation between EEC and non-EEC workers, especially regarding social and civil rights. ${ }^{62}$ In the 'Report drawn up on behalf of the Committee on Social Affairs and Employment on the problem of migrant workers', reference was made above all to the possibility of drawing up specific and differentiated texts on the 'rights of EU migrant workers'. At the same time, the report recognises that it was necessary to envisage a gradual incorporation of "non-EEC migrants with regard to certain portions of rights and duties'. The measures would therefore explicitly ensure the extension of the rights 'laid down in Regulation 1612/68 and the subsequent amendments and additions to it, in respect of the free movement of workers from third countries, following a specified period of legal residence in a Member State' ${ }^{63}$

Although the Committee on Legal Affairs did not directly refer to the proposals of the FILEF and the 'White Paper', the Italian Federation interpreted these decisions as a significant recognition of the efforts made in the 1970s and as a 'great achievement', particularly with regard to equality between workers from EEC and non-EEC countries, which had been the most problematic legal issue for a whole decade. ${ }^{64}$ For the FILEF the recognition of this achievement and the openness of the EP towards a progressive legal equalisation of all migrant workers present in the Community, without considering their origin, represented a decisive step forward towards the construction of a fairer, more equitable and solidarity-based Europe, in which migrants were considered no longer as second-class citizens but as an integral part of European civil society. During the 1980s, the FILEF did not officially submit any other petition. However, the Federation continued to play a central role in the European debate about migrant workers' rights, on the one hand through close cooperation and common projects with single MEPs ${ }^{65}$ and on the other, continuing its role as coordinator within the transnational network of migrants' organisations. It became increasingly active in international and European Committees and, since the mid-1980s, increasingly involved in the management of 'second generation' migration issues, such as assistance for political asylum seekers and war refugees, schooling problems for first generation migrants' children, and family reunions (Ireland 1991, 477-8). In Italy, too, throughout the second half of the 1980s and the early 1990s the FILEF was involved in integration and inclusion projects for foreigners in Italy, a growing challenge for both national and regional policies (Pugliese 1996 and 2000; Bonifazi 2005 , 31). At the same time, the FILEF was also affected, like other Italian 'national' migrants' organisations, by the profound transformation that affected the world of Italian migrant associations. A change linked to the democratisation processes within the Italian consular network, started 
with the founding of the official Committees of Italians Abroad (COMITES) in the mid-1980s and continued with the formation of the General Council of Italians Abroad (CGIE), a consequence of the Italian migratory agenda resulting from the Second National Conference of Emigration held in Rome in 1988 (Tintori 2016, 115). The new assistance channels for citizens living abroad, related to new migratory policies introduced by the Italian government at the beginning of the 1990s, the global social and economic changes and the evolution of the Italian emigration networks in a not necessarily association-based sense, determined a deep downsizing of the FILEF network and a general de-politicisation of the numerous initiatives still in progress with other actors of civil society.

\section{Conclusion}

With its proposed 'Statute' the FILEF intended to be fully involved in the debate on the human, civil and social rights of Italian migrant workers abroad. Through the promotion and coordination of round-table panels, meetings and working groups with the EEC institutions and thanks to its associative networks, the FILEF carried out, throughout the 1970s, an action of 'political brokerage', integrating and bringing together different social and political actors, in order to reach the common objective of a legislation aiming at respecting and safeguarding the human rights of migrant workers in the European Community. The FILEF developed not only concrete policies of common action, but also a strategic framework that could serve as a guideline to reform the existing immigration legislation in the EEC. In order to see to what extent the European Commission, particularly in the 1980s, was inspired by the proposals that the FILEF, over a whole decade, presented to the European Parliament, further studies of a historical-legal nature should certainly be carried out. Such studies go beyond the present work, which was focused more specifically on the perspective of the FILEF.

On the basis of the analysis made we are in any case able to identify two aspects, which are, in my opinion, fundamental to the understanding of the transnational political activity of the FILEF. First: although it was mainly the members of the presidency - in particular Cinanni - who carried out precise political and organisational strategies to ensure that the proposal was discussed both by the European institutions and at important international meetings and congresses, it would be misleading to see the 'White Paper' as an elitist or oligarchic initiative of the few members of the presidency. On the contrary, the 'Statute' proposal should necessarily be understood as the result of an intense debate open to contributions from the entire network of the FILEF. This established a dialogue about the proposal which was intended to involve, as democratically as possible, the Italian and European labour movement, trade unions and civil society. This debate developed, as we have seen, in two main ways. On the one hand, it was conducted through a systematic co-operation with the EEC institutions, which took place in various gatherings, meetings and round tables, in order to define which legislative form should be given to the Statute. On the other hand, it took shape through the partnership between FILEF, UNAIE and ACLI, particularly in the second half of the 1970s and aimed to overcome the ideological and political obstacles in order to find practical solutions for the problems of Italian workers and their families. Second: the speeches and writings of Paolo Cinanni show that, at the basis of the FILEF proposals for an International Statute for Migrant Rights, there was a precise vision of a 'united Europe'. The strong criticism of the so-called 'preferential clause' of the Regulation 1612/68, the proposals for wage and social security equalisation between EEC and non-EEC workers, as well as the overcoming of 'nationality' as a normative category on which to base the Community legislative apparatus in the field of migration imply, de facto, a profound reform of the political structure of the EEC, in particular from the point 
of view of social policies and in relation to the defence of human rights. Cinanni's 'Europe' is a 'Europe' in which migrant workers are at the centre of a process of democratisation of state and supranational structures and this process could be implemented only through a real political participation of migrant workers and their involvement in associations and organisations. The main example is the creating of an International Committee for Migration in Europe (formed by the FILEF and other organisations during the three International Congresses on Migration in 1971, 1974 and 1977) which would support the EEC institutions in all aspects of migration policy.

This second aspect, especially, should be further investigated. As places of political activism and social commitment - where programmes were debated, knowledge and know-how shared, action plans developed and cultural and social transfer with Italy cultivated - the Italian organisations of migrant workers were therefore (transnational) spaces of social and political 'hybridisation'. Further analysis of this facet, if conducted with an urban network and a trans-local approach (Rodger 2015; Freitag and Oppen 2005), would highlight the central and fundamental role that the Italian local associations, cultural circles and the bigger 'national' organisations of migrant workers, such as the FILEF, played in the spreading of discussion, debates and discourses about the European political, social and democratic integration. In this sense, an investigation that also considers the political involvement or the social commitment of individual migrant workers as an integral part of the migratory experience will allow a better understanding of the possible paths of redefinition and the emergence of an (individual or even collective) 'national' and/or 'European identity' among the first Italian 'guest workers' and their families (Sala 2006; Pichler 2011 and 2014).

\section{Notes}

1. There has been no monographic study so far on the FILEF. It only appears in the margins of (older but also recent) studies on the phenomenon of associationism and on Italian communities, which, however, deepen the local and urban dimension. For Federal Germany some very brief references can be found in the contributions of Breitenbach (1982), Kammerer (1991), Schöneberg (1993), Martini (2001), Prontera $(2017 ; 2018)$. For Belgium a valuable volume by Clelia Caruso (2019) was recently published, Befristete Migration und transnationaler Lebenstil, which deals with the reconstruction of the political and associative activity of the Italian community of Seraing/Liège in Belgium. In her analysis the FILEF plays an important role, since one of the main local associations of Italians, the 'Leonardo Da Vinci', became part of the FILEF network. As far as the presence of FILEF in non-European states is concerned, Simone Battiston's monograph, Immigrants Turned Activists. Italians in 1970s Melbourne (2012) should certainly be mentioned. In this volume the author examines the political and social role played by FILEF in the Italian-Australian community in Melbourne from the 1970s up to the 1990s (see Battiston 2012, xii-xiii).

2. I refer in particular to theoretical studies that link the approach of transnationalism to historical migration processes. See Glick-Schiller 1992 and 1997; Faist 2000; Bauböck and Faist 2010; Boccagni 2012; Faist et al. 2014. In particular, I use the concept of 'transnational social space', useful to describe the set of cross-border and transnational links and relationships that develop over time between individuals, collectives or through networks of organisations acting simultaneously in several states, cities or regions (see Faist 2000, 199-200; Faist et al. 2014, 61). Such an approach allows a better understanding of the multidimensionality of the transfer of ideas, discourses and political practices that, in the activities of the FILEF, contributed to the collective mobilisation within the networks of Italian migrants in Europe.

3. The body of sources I have worked on is distributed among different archives. For the first part, I mainly consulted the FILEF Archive (AF) in Rome. The bulletin Emigrazione, perfectly preserved and bound, was fundamental for the reconstruction of the initial years. Of central importance is the consultation of the 'Carlo Levi depositum', now located (at the behest of the Carlo Levi Foundation) at the Archivio Centrale dello Stato di Roma (ACSR). Alongside this set of sources, I also used grey literature (some monographs published by the FILEF) and newspaper articles, using them in a complementary way. As for the second part, the main source is the documentation concerning the 'White Paper' of the FILEF, kept in the 
Historical Archive of the European Parliament in Luxembourg (HAEP). I also used the Archive of European Integration (AEI), established by the University of Pittsburgh and fully available online.

4. Levi had already participated in the National Conference on Emigration organised by the PCI in the summer of 1967. On that occasion he had criticised the 'reformist' management of the migration problem by the Italian government, accusing the general 'philanthropic and paternalistic attitude' with which the Italian institutions managed emigration and considered it as a 'necessary and even good condition' to guarantee economic growth and to avoid socio-political tensions in Italy. As an alternative to this 'ineffective' governance, Levi proposed and invited the audience to look at emigration not only as a 'problem' and an 'instrument of power and means of preservation', but also as an opportunity to create a new international and European class consciousness and to see in the mobilisation of Italian expatriate migrants a 'new element of the workers' battles in Italy and Europe'. See Levi 1967. The copy analysed by me can be found in ACSR, Depositum 'Carlo Levi', Documentazione, b. 58-1876.

5. The aforementioned reflections of Paolo Cinanni were collected, in the same period, in the volume Emigrazione e Imperialismo (1968). The interest aroused by Cinanni's arguments, especially in left-wing revolutionary circles in the Federal Republic of Germany, led to the translation of the volume into German and its publication in 1969 entitled Emigration und Imperialismus. For a deeper and more accurate understanding of Paolo Cinanni's political ideas, see the volumes Che cos'è l'emigrazione. Scritti di Paolo Cinanni (2016) and the autobiographical volume entitled Il passato presente (una vita nel PCI.) (1986).

6. 'Oggi Assemblea costitutiva della Federazione emigrati'. In L'Unità, 21 December 1967, 3.

7. ACSR, Depositum Carlo Levi, Documentazione. b. 58-1877: Discorso sulla fondazione della FILEF (manoscritto, 1967).

8. 'Una larga unità attorno agli emigrati e alle loro famiglie'. In L'Unità, 29 December 1967, 7.

9. For example, Carlo Levi's participation in the Conference against the ban of the KPD (German Communist Party) in 1967. Many Italian workers who had emigrated to the FRG participated in this conference and many of them became part of the FILEF network in the following years. See ACSR, Depositum Carlo Levi, b. 77-2284: 'Appunti per un discorso alla Conferenza di Düsseldorf 1967'. A copy of the conference proceedings is also deposited at IISH, Coll. Bro-3088-6. As early as the 1950s and 1960s, Paolo Cinanni had also maintained relations and contacts with emigrants in Switzerland and in the south of the FRG, where he helped to build up a network of know-how that would be useful in later years. See Ricci 2016, 154.

10. The official bulletin of the Federation, published regularly since Jan. 1969 (No. 1) was printed for over 25 years. All the issues from January 1969 to December 1991 (with the exception of a few monthly issues that have been lost), are kept in the FILEF Archives and collected in a total of 23 volumes (paperback bound). In the second half of the 1990s, following the relocation of the FILEF headquarters to Via dei Frentani in Rome, an editorial reorganisation was carried out, which led to the publication of a new bulletin Emigrazione Notizie (1997) (Ricci 2007). The bulletin Emigrazione represents an inestimable source, especially with regard to its value as a 'meta-data'. First, it is a valid point of reference to corroborate the results of research in local archives. Second, the information collected in the bulletin allows a reconstruction of the existing connections between the different FILEF circles in European countries.

11. ACSR, Depositum 'Carlo Levi', Documentazione, b. 58-1878: 1878: Dattiloscritto sulla FILEF, 15 nov. 1968. See also FILEF 1975, 9-12.

12. Emigrazione No. 10, October 1969, 1-3; No. 11-12, November-December 1969, 1-6. See also 'Una giornata di lotta della emigrazione italiana', in L'Unità, 25 November 1969, 7. Of both Roman Assemblies there are also two visual testimonies: they are two black-and-white silent films, which show both the audience rooms with the participants and the podium with the members of the FILEF presidency (particularly president Carlo Levi, vice-president Luigi Gaiani and secretary Gaetano Volpe). In the short film, the slogans of the FILEF (including the most famous one: 'No longer exiled, but protagonists!') are also recognisable. These were often included in posters, on which paintings and drawings on the theme of emigration were also reproduced, made in that period by Carlo Levi (who was also a painter). See AAMOD (Archivio Audiovisivo del Movimento Operaio e Democratico, Rome), Fondo Pci, Subfondo Unitelefilm, series Non finiti, M/Pneg/1644 (December 1967) and M/Ppos/2458 (December 1969). See also the following link: https://www.youtube.com/watch?v=NSyV8oVgx4E.

13. 'Non più esiliati ma protagonisti', in L'Unità, 18 December 1969, 4; and 'Emigrazione: piaga da eliminare con la lotta di tutto il paese. Intervista con il compagno Volpe, segretario della FILEF', in L'Unità, 23 December 1969, 5.

14. Emigrazione No. 1, January 1970, 42-5. 
15. 'Perché è sorta l'ALEF, organizzazione di battaglia', in L'Unità, 1 January 1969, 4. See also Emigrazione, No. 3-4, March-April 1971, 45-6.

16. 'La FILEF ora anche in Germania'. In Corriere d'Italia, 19 January 1970, 2.

17. See Van Houte and Melgert 1972.

18. See Cinanni 1974. See also Emigrazione, No. 11-12, November-December 1974, 11-17.

19. Emigrazione No. 6, June 1977; No. 9-10, September-October 1971. See also Ricci 2016, 39-52.

20. See above all Art. 6 of the FILEF Statutes. Emigrazione, No 7-8, July-August 1971, 11-13.

21. Emigrazione No 1, January 1969, 1-6.

22. For a better understanding of the parliamentary inquiry, also in the context of Levi's political career, see his speech to the Senate on 17 January 1969. Levi 2003, 221-33.

23. Emigrazione No 4, April 1970, 21.

24. HAEP (Historical Archive of the EP), EP(EP), 17 May 1971. Draft report on Petition No 4/70 concerning the improvement of the situation of Italian emigrants in the Community and the adoption of a European statute for migrant workers, 6 .

25. Emigrazione No. 12, December 1970. See the part entitled 'Libro Bianco' I, 3.

26. Regulation (EEC) No. 1612/68 of the Council of 15 October 1968 on freedom of movement for workers within the Community.

27. Emigrazione No. 12, December 1970.

28. HAEP, EP, 18.06.1971. Report presented on behalf of the Social and Health Committee on Petition No. $4 / 70$ concerning the improvement of the situation of Italian emigrants in the Community and the adoption of a European statute for migrant workers, 6 .

29. Emigrazione No. 12, December 1970, VI 4.

30. Ibid.

31. HAEP, EP, 17.05.1971. Draft report on Petition No 4/70, cit., 5.

32. Emigrazione, No. 3-4, March-April 1971.

33. AEI (Archive of European Integration). Commission of the European Communities (17 March 1971). Preliminary guidelines for a Community social policy program. SEC (71) 600 final, 17 March 1971. Bulletin of the European Communities, Supplement 2/71.

34. Here is the original quote: 'The extent of the movement of foreign labour and the fact that more and more workers are natives of more distant countries have changed considerably the nature of the problems raised by immigration. The cultural gap between workers and the population of the host countries has widened. In some circles, there is resistance to or distrust of a foreign "presence" which is sometimes regarded as excessive.' AEI, Preliminary Guidelines, cit., 19-20.

35. Ibid. 59.

36. Emigrazione No. 6, June 1971, 1-7, here 6-7.

37. Cinanni 1972, 27-36, here 34-6. The emphases are in the original text. For the Italian version see also Ricci 2016, 39-52 and Emigrazione, No. 9, September 1971, 19-24.

38. See Alfred Califice's speech at the sitting of the European Parliament, published in: HAEP, EP, Debates of the EP (21.09.1971): Sitting of Tuesday 21 September 1971, 7-8.

39. See Regulation (EEC) No 1612/68, Art. 7-9.

40. See the intervention by Albert Coppè in: HAEP, EP, Debates of the EP (21.09.1971): Sitting of Tuesday 21 September 1971, 12-14 (here 13).

41. Ibid. 15 .

42. HAEP, EP (19 April 1974): Draft revised report on Petition No 1/73 concerning a proposal for an International Statute for Migrant Rights and Petition No 1/74 concerning proposals for a European Migrant Workers' Statute, 7.

43. See in particular the large participation of the trade unions and workers in the third national FILEF congress, held in Bari in December 1971. The congress was attended by over 200 delegates from Italian workers' associations abroad. See Corriere d'Italia, 13 January 1972, 4. On that occasion too, awareness was raised towards greater adherence of trade unions, Italian cultural and political associations and civil society in general to the Statute project. See in particular the report by Gaetano Volpe, Emigrazione No. 1-2, January-February 1972, 6-14, in particular on page 13. See also 'Forte impegno della Filef per il lavoro e le riforme', in L'Unità, 5 January 1972, 11.

44. See above all: 'La proposta UNAIE per uno Statuto Europeo sui diritti del lavoratore migrante', in Presenza UNAIE. Bollettino d'Informazione, Year III, No. 7, July 1973, 15-23. The monthly bulletins of the UNAIE analysed by me are kept in IISH (International Institute for Social History), Coll. ZK30362. 
45. Draft revised report on Petition No $1 / 73$.

46. Draft revised report on Petition No 1/73, 10-11.

47. EU, Debates of the EP. Sitting of Wednesday 12 June 1974.

48. Emigrazione No. 7-8, July-August 1974, 6-27.

49. AEI, Report drawn up on behalf of the Committee on Social Affairs and Employment on the social Action Programme submitted by the Commission of the European Communities to the Council (Doc. 216/73). EP Working Document, Document 1973-4 256/73, 6 December 1973, 14.

50. I report, for the sake of clarity, the quote by Girardin as transcribed (in Italian) in the documentation: 'Sarebbe utile che le associazioni presentatrici di loro proposte chiarissero se lo Statuto debba valere per tutti o solo per i comunitari'. Emigrazione, 7-8, July-August 1974, 16.

51. Cinanni 1974, 115.

52. Emigrazione No. 10, October 1974.

53. Emigrazione No. 10, October 1974, 9.

54. Emigrazione No. 10, October 1974, 11.

55. AEI, Commission of the European Communities (December 1974): Information memo. Action Program for Migrant Workers and their Families, Doc. P-85/74, 1-3.

56. On that occasion, the three large 'national' organisations of Italian migrants produced a unitary programmatic document, which was then read and discussed during the final plenary session of the congress. Emigrazione No. 3-4, March-April 1975, 50-53 (see especially the 'Comunicazione di Paolo Cinanni'). For the unitary programmatic document, see the report by Marino Carboni, national president of ACLI in Conferenza Nazionale dell'Emigrazione 1975, 125-62.

57. Emigrazione No. 6, June 1977. The entire issue is dedicated to speeches, committee reports, press reports and the final document.

58. Emigrazione No. 6. June 1977, 53-58, here 53.

59. Emigrazione No. 11, November 1979, 17-40, here 37.

60. HAEP, EU (December 1979). Correspondence between Paolo Cinanni and Simone Veil, 1-2.

61. AEI, European Parliament (15.11.1979): Motion for a resolution tabled by Mr Ceravolo, Mr Dido et al., Doc. 1-516/79. See also AEI, European Parliament (30 November 1979): Motion for a resolution tabled by Mrs Cassanmagnago Cerretti et al., Doc. 1-535/79/rev.

62. HAEP, PE 71.941. EP, Legal Affairs Committee. Minutes of the meeting of Tuesday 17 February 1981 and Wednesday 18 February 1981, 11. See also HAEP, PE 72.243. EP, Legal Affairs Committee. Minutes of the meeting of Wednesday, 25 February 1981 and Thursday, 26 February 1981, 4.

63. HAEP, EU (17 October 1983): Report drawn up on behalf of the Committee on Social Affairs and Employment on the problem of migrant workers, 28.

64. Emigrazione No. 4, April 1981.

65. Emigrazione No. 5, May 1981, 37.

\section{References}

Bade, K. J. 2003. Migration in European History. Malden: Blackwell.

Battiston, S. 2004. History and Collective Memory of the Italian Migrant Workers' Organisation FILEF in 1970s Melbourne. PhD diss., La Trobe University, Melbourne, Australia.

Battiston, S. 2012. Immigrants turned Activists. Italians in 1970s Melbourne. Kibworth Beauchamp: Troubador Publishing.

Bauböck, R. and T. Faist. 2010. Diaspora and Transnationalism. Concepts, Theories and Methods. Amsterdam: Amsterdam University Press.

Boccagni, P. 2012. 'Revisiting the "Transnational" in Migration Studies: A Sociological Understanding'. REMI (Revue Européenne des Migrations Internationales) 28 (1): 33-50.

Bonifazi, C. 2005. 'Dall'emigrazione assistita alla gestione dell'immigrazione: le politiche migratorie nell'Italia repubblicana dai vecchi ai nuovi scenari del fenomeno'. Popolazione e storia 6 (1): 19-43.

Breitenbach, B. von. 1982. Italiener und Spanier als Arbeitnehmer in der Bundesrepublik Deutschland. Eine vergleichende Untersuchung zur europäischen Arbeitsmigration. Munich: Kaiser-Grünewald.

Canovi, A. 2011. 'L'immagine degli Italiani in Belgio. Appunti geostorici'. Diacronie. Studi di Storia Contemporanea (5): 1-16. 
Carta, D. 2011. 'Non più cose ma protagonisti'. L'associazionismo tra gli emigrati italiani in Belgio e Svizzera, 1945-2001. Il caso di Bruxelles e Ginevra. PhD diss., University of Bergamo, Italy.

Caruso, C. 2019. Befristete Migration und transnationaler Lebensstil. Italienerinnen und Italiener in einer wallonischen Bergbaugemeinde nach 1945. Cologne: Böhlau Verlag.

Cinanni, P. 1968. Emigrazione e imperialismo. Rome: Editori Riuniti.

Cinanni, P. 1969. Emigration und Imperialismus. Zur Problematik der Arbeitsmigranten. Munich: Trikont.

Cinanni, P. 1972. 'The Backgrounds of Migrant Labour'. In Foreigners in Our Community. A New European Problem to be Solved, edited by H. van Houte and W. Melgert, 27-36. Amsterdam: Keesing.

Cinanni, P. 1974. 'Legal Status and Rights for Migrant Workers'. In Migrants in Europe: Plights and Prospects. A Report of the First Pan European Conference of Migrant Workers, Wageningen, The Netherlands, 22-24 November, edited by G. M. de Boer and B. T. van der Wal, 104-06.

Colucci, M. 2001. 'L'associazionismo di emigrazione nell'Italia repubblicana'. In Storia dell'emigrazione italiana. Partenze, edited by P. Bevilacqua, A. De Clementi and E. Franzina, 415-29. Rome: Donzelli.

Colucci, M. 2008. 'L'emigrazione italiana negli anni Sessanta'. In Rapporto Italiani nel Mondo 2008, 93-99. Rome: Fondazione Migrantes.

Colucci, M. and M. Sanfilippo. 2010. Guida allo studio dell'emigrazione italiana. Viterbo: Edizioni Sette Città.

Conferenza Nazionale dell'Emigrazione. 1975. L'emigrazione italiana nelle prospettive degli anni Ottanta. Atti della Conferenza Nazionale dell'Emigrazione. Roma, 24 febbraio-1 marzo 1975. Rome.

De Donato, G. and S. D'Amaro. 2005. Un torinese del Sud. Carlo Levi: una biografia. Milan: Baldini Castoldi Dalai.

Faist, T. 2000. The Volume and Dynamics of International Migration and Transnational Social Spaces. Oxford: Oxford University Press.

Faist, T., M. Fauser, E. Reisenauer, D. D'Urso and C. Ferdinand-Gonzalez. 2014. Das Transnationale in der Migration. Eine Einführung. Weinheim: Beltz Juventa.

FILEF. 1975. Emigrazione verso la crisi. Nuovo diritto, fine dell'esodo e delle congestioni nei programmi della FILEF. Rome: Edizioni FILEF.

Freitag, U. and A. von Oppen. 2005. Translokalität als ein Zugang zur Geschichte globaler Verflechtungen. (ZMO Programmatic Texts, 2). Berlin: Zentrum Moderner Orient. https://nbn-resolving.org/urn:nbn: de:0168-ssoar-427594

Gilardoni, G., M. D'Odorico and D. Carrillo. 2015. Evidence on Migrants' Integration in Europe. Milan: Fondazione ISMU. http://www.king.ismu.org/wp-content/uploads/KING_Report.pdf

Glick-Schiller, N., L. Basch and C. Blanc-Szanton. 1992. 'Transnationalism: A New Analytic Framework for Understanding Migration'. In Towards a Transnational Perspective on Migration. Race, Class, Ethnicity, and Nationalism Reconsidered, edited by N. Glick-Schiller, L. Basch and C. Blanc-Szanton, 1-24. New York: New York Academy of Sciences.

Glick-Schiller, N., L. Basch and C. Blanc-Szanton. 1997. 'From Immigrant to Transmigrant: Theorizing Transnational Migration'. In Transnationale Migration, edited by L. Pries, 121-140. Baden-Baden: Nomos.

Ireland, P. R. 1991. 'Facing the True "Fortress Europe": Immigrant and Politics in the EC'. Journal of Common Market Studies Vol. XXIX (5): 457-80.

Kaiser, W. 2005. 'Transnational Western Europe since 1945. Integration as political society formation'. In Transnational European Union. Towards a Common Political Space, edited by P. Starie and W. Kaiser, 17-35. London: Routledge.

Kaiser, W. and J.-H. Meyer. 2010. 'Non-State Actors in European Integration in the 1970s: Towards a Polity of Transnational Contestation'. In Non-state Actors in European Integration in the 1970s. Towards a Polity of Transnational Contestation, edited by W. Kaiser, J.-H. Meyer and S. Bietz, 7-24. Leipzig: Leipziger Universitätsverlag. 
Kammerer, P. 1991. 'Some problems of Italian Immigrants Organizations in the Federal Republic of Germany'. In Ethnicity, Structured Inequality and the State in Canada and the Federal Republic of Germany, edited by R. Ostow and J. Fijalkowski, 185-96. Frankfurt am Main: Lang.

Kammerer, P. 2005. 'Storie di vita, di sviluppo e di sbandamento tra sud e nord'. La Critica Sociologica (156): 80-95.

Kocka, J. 2000. 'Zivilgesellschaft als historisches Problem'. In Europäische Zivilgesellschaft in Ost und West. Begriff, Geschichte, Chancen, edited by M. Hildermeier, J. Kocka and C. Conrad, 13-40. Frankfurt am Main: Campus Verlag.

Laschi, G., V. Deplano and A. Pes, eds. 2020. Europe between Migrations, Decolonization and Integration (1945-1992). Abingdon, Oxon and New York: Routledge.

Levi, C. 1967. 'Coscienza dell'emigrante'. Rinascita 2, January: 28.

Levi, C. 2003. Discorsi Parliamentari. Senato della Repubblica Archivio Storico. Bologna: Il Mulino.

Lotterer, J. 2014. 'Vereinsüberlieferung als Zugang zur lokalen Migrationsgeschichte'. In Archive und Migration. Vorträge des 73. Südwestdeutschen Archivtags am 21. und 22. Juni 2013 in Stuttgart, edited by R. Deigendesch and P. Müller, 69-77. Stuttgart: Kohlhammer.

Lucassen, L., D. Feldman and J. Oltmer, eds. 2010. Paths of Integration. Migrants in Western Europe (1880 2004). Amsterdam: Amsterdam University Press.

Marin, L. 2016. 'FILEF: An Example of Social and Political Engagement of Italians in Australia'. In The European Diaspora in Australia. An Interdisciplinary Perspective, edited by B. Mascitelli, S. Mycak and S. Papalia, 73-91. Newcastle-upon-Tyne: Cambridge Scholars Publishing.

Martini, C. 2001. Italienische Migranten in Deutschland: transnationale Diskurse. Berlin: Reimer.

Palidda, S. 2005. 'L'associazionismo italiano in Francia'. In Studi Emigrazione XLII (160): 919-34.

Pichler, E. 2011. 'Die Italiener in Berlin und ihr Selbstverständnis als neue Europäer'. In Dolce Vita? Das Bild der italienischen Migranten in Deutschland, edited by O. Janz and R. Sala, 277-94. Frankfurt am Main: Campus Verlag.

Pichler, E. 2014. 'Dai vecchi pionieri alla nuova mobilità. Italiani a Berlino tra inclusione ed esclusione'. In Italo-Berliner. Gli italiani che cambiano la capitale tedesca, edited by E. De Salvo, L. Priori and G. Ugolini, 25-40, Milan: Mimesis.

Prontera, G. 2017. 'Munich - City of Immigration? Integration Policies and Italian Active Participation in Munich Political and Social Life through Italian Organisations in the 1970s'. In Cities Contested. Urban Politics, Heritage, and Social Movements in Italy and West Germany in the 1970s, edited by M. Baumeister, B. Bonomo and D. Schott, 147-168. Frankfurt am Main: Campus Verlag.

Prontera, G. 2018. 'Die städtische Integrationspolitik und die Teilhabe der Italiener am politischen und gesellschaftlichen Leben in München'. In Migration bewegt die Stadt. Perspektiven wechseln, edited by U. Eymond and A. Heusler, 34-41. Munich: Allitera.

Pugliese, E. 1996. 'Italy between Emigration and Immigration and the Problems of Citizenship'. In Citizenship, Nationality, and Migration in Europe, edited by D. Cesarani and M. Fulbrook, 106-21. London: Routledge.

Pugliese, E. 2000. 'Tra migrazioni internazionali e migrazioni interne'. In Politica Internazionale (4-5): 229-68.

Pugliese, E. 2006. 'L'emigrazione italiana in Germania: mercato del lavoro e politiche migratorie'. In Andare, restare, tornare. Cinquant'anni di emigrazione italiana in Germania, edited by F. Carchedi and E. Pugliese, 19-44. Isernia: Cosmo.

Ricciardi, T. 2013. Associazionismo ed emigrazione. Storia delle colonie libere e degli Italiani in Svizzera. Rome: Laterza.

Ricci, R., ed. 2007. 1997-2007. Dieci anni di migrAzioni. Rome: Edizioni FILEF.

Ricci, R., ed. 2016. Che cos'è l'emigrazione. Scritti di Paolo Cinanni. Rome: Edizioni FILEF.

Richter, H. and R. Richter. 2012. Die Gastarbeiter-Welt. Leben zwischen Palermo und Wolfsburg. Paderborn: Schöningh.

Rodger, R. 2015. 'Reflections: Putting the "Trans" into Transnational Urban History'. In Cities Beyond Borders. Comparative and Transnational Approaches to Urban History, edited by N. Kenny and R. Madgin, 207-16. Farnham, Surrey, Burlington, VT: Ashgate. 
Sala, R. 2006. 'Die Nation in der Fremde. Zuwanderer in der Bundesrepublik Deutschland und nationale Herkunft aus Italien'. In Historische Integrationssituationen. IMIS Beiträge 29, edited by J. Oltmer, 99-122. Osnabrück, Germany: University of Osnabrück.

Sanfilippo, M. 2011: 'Cronologia e storia dell'emigrazione italiana'. Studi Emigrazione XLVIII (183): 357-70.

Schoeneberg, U. 1993. Gestern Gastarbeiter, morgen Minderheit. Zur sozialen Integration von Einwanderern in einem 'unerklärten' Einwanderungsland. Frankfurt am Main: Lang.

Spatolisano, F. 2012. 'Note su Paolo Cinanni e il suo impegno politico e intellettuale'. Rivista Calabrese di Storia del '900 (2): 181-8.

Tintori, G. 2016. 'Italian Mobilities and Demos'. In Italian Mobilities, edited by R. Ben-Ghiat and S. M. Hom, 111-32. London/New York: Routledge.

Van Houte, H. and W. Melgert. 1972. Foreigners in our Community. A New European Problem to be Solved. Amsterdam: Keesing.

Zölls, P. 2019. Regieren der Migration. Von Einwanderungsprozessen und staatlichen Regulierungspolitiken. Munich: Allitera.

\section{Appendix}

\section{Archival sources}

\section{AEI, Archive of European Integration, University of Pittsburgh}

Commission of the European Communities (17 March 1971): Preliminary guidelines for a Community social policy program. SEC (71) 600 final, 17 March 1971. Bulletin of the European Communities, Supplement 2/71. http://aei.pitt.edu/5597/1/5597.pdf.

European Parliament (6 December 1973): Report drawn up on behalf of the Committee on Social Affairs and Employment on the social Action Programme submitted by the Commission of the European Communities to the Council (Doc. 216/73). EP Working Document, Document 1973-1974 256/73, 6 December 1973. http://aei.pitt.edu/97325/1/1973-74.73.256.pdf

Commission of the European Communities (December 1974): Information memo. Action Program for Migrant Workers and their Families, P-85/74. http://aei.pitt.edu/30305/1/P_85_74.pdf.

Commission of the European Communities (23 March 1979): Consultation on Migration Policies via-a-vis Third Countries. Communication of the Commission to the Council. COM (79) 115 final, 23 March 1979, COM (79) 115. http://aei.pitt.edu/1097/1/migration_COM_79_115.pdf.

European Parliament (15 November 1979): Motion for a resolution tabled by Mr Ceravolo, $\mathrm{Mr}$ Dido', Mrs Castellina, Mr Ferri, Mr Arfe, Mr Gatto, Mrs Squarcialupi, Mrs Baduel Glorioso, Mr Cardia, Mr d'Angelosante, Mr de Pasquale, Mr Papapietro and Mr Bonaccini pursuant to Rule 25 of the Rules of Procedure on the Statute for migrant workers. Working Documents 1979-1980, Document 1-516/79, 15 November 1979. http://aei.pitt.edu/61691/.

European Parliament (30 November 1979): Motion for a resolution tabled by Mrs Cassanmagnago Cerretti, Mr Barbagli, Mrs Maij-Weggen, Mr Nordlohne, Mr Verhaegen, Mr McCartin, Mr Spautz, Mrs Moreau, Mr Dalsass, Mr Ghergo, Mr Wawrzik, Mr von Bismarck and Mr Vandewiele. Working Documents 1979-1980, Document 1-535/79/rev., 30 November 1979. Archive of European Integration (AEI), Doc. 1-535/79/rev. http://aei.pitt.edu/61689/1/EPWD_2pp_B8_152.pdf.

\section{HAEP, Historical Archive of the European Parliament, Luxemburg}

EP (European Parliament), Draft report on Petition No 4/70 concerning the improvement of the situation of Italian emigrants in the Community and the adoption of a European statute for migrant workers, 17 May 1971. EU.HAEU/PE0.AP.ASOC.1967.RP//A0-0051/71/0020 (DE, FR, IT). 
EP, Report presented on behalf of the Social and Health Committee on Petition No 4/70 concerning the improvement of the situation of Italian emigrants in the Community and the adoption of a European statute for migrant workers, 18 June 1971 EU.HAEU/PE0.AP.ASOC.1967.RP// A0-0051/71/0010 (DE, FR, IT).

EP, Debates of the EP 21 September 1971. EU.HAEU/PE0.AP.DE.1971//DE19710921-04 (DE, FR, IT)

EP, 19 April 1974: Draft revised report on Petition No 1/73 concerning a proposal for an International Statute for Migrant Rights and Petition No 1/74 concerning proposals for a European Migrant Workers' Statute. EU.HAEU/PE0.AP.ASOC.1973.RP//A0-0084/74/0010 (DE, FR, IT, EN)

EU, Debates of the EP 12 June 1974.EU.HAEU/PE0.AP.DE.1974//DE19740612-01(DE, FR, IT, EN)

EU (December 1979), Correspondence between Paolo Cinanni and Simone Veil, President of the European Parliament. EU.HAEU/PE1.P1.200/PRES.270/RINT.272/COMP//ASOC.1979-120/0040

EP. Legal Affairs Committee (24 February 1981): Minutes of the meeting of Tuesday, 17 February 1981 and Wednesday, 18 February 1981. EU.HAEU/PE1.AP.JURI.1979.PV//JURI-19810217/ 0010 (FR, EN)

EU. Legal Affairs Committee (09 March 1981): Minutes of the meeting of Wednesday, 25 February 1981 and Thursday, 26 February 1981. EU.HAEU/PE1.AP.JURI.1979.PV// JURI-19810225/0010 (FR, EN)

EP (17 October 1983): Report drawn up on behalf of the Committee on Social Affairs and Employment on the problem of migrant workers. EU.HAEU/PE1.AP.ASOC.1979.RP// A1-0811/83/0010 (DE, FR, IT, EN)

\section{AF, Archivio FILEF, Rome}

Emigrazione (official FILEF bulletin), 1969-92 (uninventorised)

\section{ACSR, Archivio Centrale dello Stato, Rome, Depositum 'Carlo Levi', Documentazione:}

b. 58-1876: Intervento alla Conferenza Nazionale sull'Emigrazione, in Rinascita, 13 January.1967

b. 58-1877: Discorso sulla fondazione della FILEF (manoscritto, 1967)

b. 58-1878: 1878: Dattiloscritto sulla FILEF, 15 November 1968.

b. 77-2284: Appunti per un discorso alla Conferenza di Düsseldorf 1967

\section{AAMOD, Archivio Audiovisivo del Movimento Operaio e Democratico, Rome}

Fondo PCI, Subfondo Unitelefilm, serie Non finiti, M/Ppos/2458

Fondo PCI, Subfondo Unitelefilm, serie Non finiti, M/Pneg/1644

\section{IISH, International Institute for Social History, Amsterdam}

ZK30362 (collection of UNAIE bulletins)

Bro-3088-6 


\section{Newspaper articles and internet sources}

Corriere d'Italia, 1970-71

L'Unità, 1969-71. Link: https://archivio.unita.news/ (last accessed 24 June 2020)

Regulation (EEC) No 1612/68 of the Council of 15 October 1968 on freedom of movement for workers within the Community. Link: https://eur-lex.europa.eu/eli/reg/1968/1612/oj/?uri= CELEX:31968R1612 (last accessed 24 June 2020)

\section{Italian summary}

L'articolo analizza il contributo della FILEF (Federazione Italiana Lavoratori Migranti e Famiglie) al dibattito europeo sui diritti umani, sociali e civili dei lavoratori migranti nel corso degli anni Settanta. Attraverso il progetto di uno "Statuto internazionale dei diritti dei lavoratori migranti", presentato al Parlamento Europeo all'inizio degli anni Settanta, la FILEF avanzò una proposta di riforma del regolamento comunitario del 1968 sulla libera circolazione dei lavoratori migranti in Europa, al fine di estendere anche ai lavoratori provenienti dai paesi extra-europei gli stessi diritti e tutele riconosciuti a quelli dall'area CEE. Al centro dell'analisi sono, da un lato, i diversi stadi di discussione della proposta nelle commissioni del Parlamento Europeo, dall'altro, i momenti principali del dibattito che si sviluppò nel network transnazionale della FILEF in occasione delle conferenze internazionali organizzate dalla Federazione dalla metà degli anni Settanta fino all'inizio degli anni Ottanta. 